\title{
ALLOGENEIC BONE MARROW MULTIPOTENT MESENCHYMAL STROMAL CELLS AND POLYTRAUMA REPAIR: THE ROLE OF FRACTIONATED ON THE BASIS OF MOLECULAR MASS RED BEETROOT JUICE IN THE PREVENTION OF TRANSPLANTED CELLS SIDE EFFECTS IN RATS
}

\author{
Dmitrijs Babarikins*, Guntra Krūmiṇa*, Irina Paegle**, Diāna Amerika ***, \\ Zaiga Krūmiṇa*, Dmitrijs Vanags *, and Tatjana Tihomirova* \\ * Institute of Innovative Biomedical Technology, Inčukalna iela 2, Rīga, LATVIA; \\ office@ akd.apollo.lv; guntra.krumina@gmail.com \\ ** Rīga Hospital of Traumatology and Orthopedics, Duntes iela 12/22, Rīga, LV-1013, LATVIA \\ *** Pauls Stradinš University Hospital, Latvian Transplantation Centre, Pilsonu iela 13, Rīga, LV-1002, LATVIA
}

Communicated by Rafails Rozentāls

\begin{abstract}
Red beetroot (Beta vulgaris) juice (RBJ) is used as a traditional medicine for treatment of anemia. It has been shown that beetroot juice decreases blood pressure, provides a protective effect on blood vessels and has antioxidant and anticancerogenic properties. In the case of polytrauma it might have beneficial effects because of its antioxidant and anti-inflammatory properties as well as antimicrobial activity. It is also well-known that RBR juice can induce undesirable side effects, e.g. flatulent stomach, nausea and other unpleasant reactions. Therefore, it seems prospective to develop red beetroot juice based on its natural compound composition free of undesirable side effects, which could then be used in combination with bone marrow multipotent mesenchymal stromal cells (BM MMSC) transplantation in the case of polytrauma. The aim of the study was to evaluate the therapeutic effect of allogeneic BM MMSC transplantation in rats with experimental polytrauma and to analyse red beetroot fractions separated on the basis of molecular weight in regard to their ingestion impact on cell transplantation efficacy. Red beet juice was fractionated by ultrafiltration (cut-off-point $20 \mathrm{kDa}$ ). Total phenolic compound concentration in the final product practically did not decrease. The product was tested in vitro and in vivo. Unlike native juice, fractionated RBJ in vitro suppressed BM MMSC adipogenic $(60-71 \%, \mathrm{P}<0.05)$ and stimulated osteogenic differentiation (124\%, $\mathrm{P}<0.05)$. Experimental polytrauma in rats was modelled by causing three fractures and haemorrhagic shock. Animals were randomised in five groups: 1) normal control; 2) polytrauma; 3) polytrauma $+i / v B M M M S C$ transplantation $36 \mathrm{~h}$ and 5 days after surgery; 4) polytrauma + fractionated RBJ administration per os $1 \mathrm{ml} / \mathrm{d}$, and 5) polytrauma $+B M$ MMSCs + fractionated RBJ. Transplantation of allogeneic BM MMSCs in rats with experimental polytrauma stimulated bone fracture reparation, but caused plethora in viscera and dystrophic changes in lungs. Combination of BM MMSCs and fractionated RBJ resulted in better bone reparation and significant hematopoiesis stimulation.
\end{abstract}

Key words: bone fractures, haemorrhagic shock, Beta vulgaris, fractionation by molecular mass, multipotent mesenchymal stromal cells, acid/base balance.

\section{INTRODUCTION}

Polytrauma is a clinical condition defined by the presence of at least two long bone fractures, or one life-threatening injury and at least one additional injury, or severe head trauma and at least one additional injury (Pape et al., 2006). Polytrauma patients usually undergo complex medical management and, in particular, treatment of these patients will generally require resuscitation, emergency surgery, inten- sive care and complex reconstructive surgery (Sikand et al., 2005).

Rehabilitation of polytrauma victims requires the use of technologies that offer tissue and organ regeneration capabilities. An example of such a technology is stem cells.

In this case, bone marrow multipotent mesenchymal stromal cells (BM MMSCs) look promising, because their 
isolation is not linked to technical and ethical difficulties. BM MMSCs can differentiate and form fat, bone and cartilage cells. Despite the potential of trans-differentiation, their usage within regenerative medicine is better biologically proven in regard to the bone tissue reparation, because they are naturally inclined to differentiate in osteogenic lineage (Murglia et al., 2000). MMSCs have anti-inflammatory as well as haematopoiesis-linked effects (Williams et al., 2011). Thus, it is reasonable to use MMSCs for treatment of bone disorders - complicated bone fractures, bone metabolic diseases, in rheumatology etc.

It has been suggested that for better clinical results BM MMSC differentiation to desired cell type should be induced in vitro (Lian et al., 2010; Jorgensen et al., 2004) due to improved controllability compared to in vivo (Javazon et al., 2004). For osteogenic differentiation of MMSCs different chemical agents (Paderni et al., 2009) as well as matrix structural organisation are used (Malginov et al., 2009).

As it is known, a large number of factors participate in the regulation of MMSC differentiation in vivo, i.e. growth factors, chemokines, cytokines, hormones and physical factors (Augello and de Bari, 2010). It is believed that stem cell transplantation treatment is more effective when the fate of cells is further affected. Substances that are used for manipulation of stem cells in vitro are not always clinically applicable due to the technology-related safety issues. Over the last several years, there have been several published studies on the use of simvastatin and lovastatin to improve the viability of MMSCs after transplantation (Xu et al., 2008; Yang et al., 2009). Based on this, the oral use of natural substances, especially ones of plant origin that could be used for cell transplantation in the clinic, becomes rather appealing.

Red beetroot (Beta vulgaris) juice (RBJ) is used as a food colorant, additive to cosmetics and as a traditional medicine for treatment of anemia. In high doses, beetroot juice has shown that it decreases blood pressure, provides protective effect on blood vessels (Webb et al., 2008) and has antioxidant (Georgiev et al., 2010) and anticancerogenic properties (Kapadia et al., 2003). Due to high phenolic compound concentration in the case of polytrauma it could have beneficial effects because of its antioxidant (Escribano et al., 1998) and anti-inflammatory properties (Winkler et al., 2005) as well as antimicrobial activity (Velićanski et al., 2011). It is also a well-known that RBJ can induce undesirable side effects, e.g. flatulent stomach, nausea and other unpleasant reactions. Regular consumption of large doses of the RBJ can cause serious hepatological problems (Blázovics et al., 2007). Many potential consumers refuse to drink RBJ because of its specific taste and smell. Therefore, it seems prospective to develop red beetroot juice based on its natural compound composition free of undesirable side effects, which could then be used in combination with MMSC transplantation in the case of polytrauma.

The aim of the study was to evaluate the therapeutic effect of allogeneic BM MMSC transplantation in rats with exper- imental polytrauma and to analyse the impact of ingestion of RBJ fraction separated on the basis of molecular weight on cell transplantation efficacy.

\section{MATERIALS AND METHODS}

\section{Study design}

- RBJ extraction and fractionation by ultrafiltration,

- native RBJ and fractionated RBJ chemical analysis,

- BM MMSCs isolation and obtained cell identification,

- RBJ impact on BM MMSC differentiation in vitro study,

- evaluation of therapeutic efficacy of allogeneic BM MMSC transplantation in combination with fractionated RBJ per oral ingestion in rats with experimental polytrauma.

Red beet juice fractionation. Fractionated juice was obtained by sequential filtrations of freshly extracted RBJ through bag filters with pore size $250,50,5$ and $1 \mu \mathrm{m}$, followed by ultrafiltration through a ceramic filter with cutoff-point $20 \mathrm{KDa}$ (patent pending). In the experiments native and fractionated RBJ prepared from the same vegetable batch was used.

In both kinds of RBJ samples, concentrations of the following compounds were determined: red pigment betacyanins (calculated in terms of betanin), yellow pigment betaxanthins (calculated in terms of vulgaxanthin-I), betaine, total phenolic content, iron, and sugars.

Animals. Male Wistar-Kyoto rats were maintained on a standard rat diet and water ad libitum. The animals were housed in rodent cages with seven rats in each cage. The dark-light cycle was $12 \mathrm{~h} / 12 \mathrm{~h}$.

The experiment was approved by the local Animal Ethics Committee.

Cell culture experiments. Rat BM MMSCs were harvested from femurs and tibias of 130-150 g male Wistar-Kyoto rats by flushing bone with complete DME medium supplemented with $10 \%$ FBS, 2 mM L-glutamine, $100 \mathrm{U} / \mathrm{ml}$ penicillin and $100 \mathrm{mcg}$ streptomycin (all from Sigma). The recovered cells were plated on $75 \mathrm{~cm}^{2}$ tissue culture flasks. After $24 \mathrm{~h}$ the nonadherent cells were removed by replacing the medium. When the cells reach $70 \%$ confluency, they were harvested with $0.25 \%$ trypsin/ $1 \mathrm{mM}$ EDTA (Sigma).

Harvested rat BM MMSCs at passage 4 were stained with anti-CD45-FITC (Becton Dickinson) and anti-CD90-PE and analyzed by flow cytometry (EpicXL, Beckman Coulter).

Osteogenic and adipogenic differentiation of rat BM MMSC was induced according to a published protocol with some modification (Freshney et al., 2007). Osteogenic differentiation was evaluated using Alizarine red (Sigma) 
staining and detection of alkaline phosphatase activity. Adipogenesis was assayed by staining intracellular lipid droplets with Oil red O (Sigma).

To assess impact on differentiation of rat BM MMSCs starting from the day of induction of differentiation, native and fractionated RBJ were added to standard cultivation or differentiation induction medium in the following concentrations: $0.1 \%$ and $0.3 \%$.

Experimental polytrauma in rats. Polytrauma was induced by causing multiple fractures and haemorrhagic shock under general anesthesia with intraperitoneal injection of ketamine/medetomidine/atropine $(75 / 0.5 / 0.5 \mathrm{mg} / \mathrm{kg})$. Fractures were provoked by clamping both femurs and the right tibia. No fixation of fractures was used during recovery. Haemorrhagic shock was induced by $3.5-4.0 \mathrm{ml}$ withdrawal of blood from the sublingual vein. After $60 \mathrm{~min}$ animals received fluid resuscitation by infusing $2 \mathrm{ml}$ of saline. Thereafter, the rats were maintained on water containing $0.15 \mathrm{mg} / \mathrm{ml}$ ibuprofen for at least two weeks.

Rats were randomly divided into five groups:

Group 1 - Control;

Group 2 - Polytrauma;

Group 3 - Polytrauma + BM MMSCs;

Group 4 - Polytrauma + fractionated RBJ;

Group 5 - Polytrauma + BM MMSCs + fractionated RBJ.

In $36 \mathrm{~h}$ and in 5 days after surgery $1 \times 10^{6}$ BM MMSCs were $\mathrm{i} / \mathrm{v}$ injected for groups 3 and 5 . Starting from the surgery day, animals from groups 4 and 5 received $1 \mathrm{ml} / \mathrm{d}$ of fractionated red beetroot juice per os. Rat weight and rectal temperature was measured every other day during the 30 days of the experiment.

Blood analysis. At the days 3 and 10 of the experiment venous blood from each rat was analyzed using a blood gas analyser RapidLab® 1265 (Siemens, Germany).

In addition, the day before the operation, at day 3 and 10 , and at the end of the experiment, heparinised blood was drawn for blood element analysis on Cell-Dyn ${ }^{\circledR} 3700$ (Abbott, USA).

At the end of the experiment, $2 \mathrm{ml}$ of blood was collected for biochemical analysis (blood serum creatinine, urea, alanine aminotransferase (ALT) and aspartate aminotransferase (AST)) performed on a ILAB 300+ (Instrumentation Laboratory, USA).

Histological study. Thirty days after the polytrauma, animals were euthanised using cervical dislocation, and organs including lungs and kidney as well as fractionated extremities were harvested. Lower extremity muscles together with their tendons were weighed immediately following dissection. For histological examination, lungs, kidney and bones after callus macroscopic examination were fixed in $4 \%$ paraformaldehyde. The specimens were dehydrated in ascending grades of ethanol and embedded in paraffin. Bone decalcification was conducted using a TBD-2 Decalcifier (Shandon). Sections of $5 \mathrm{~mm}$ in thickness were prepared and stained with hematoxilin (Bio Optica) end eosin (DiaPath) and then examined under light microscopy. Histological analysis was performed by a blinded observer.

Statistical analysis was performed using Excel 2003. All results are expressed as mean \pm standard deviation of the mean of three or more measurements. A two-sided, paired $t$ test was used, and differences were considered significant at $P<0.05$.

\section{RESULTS}

Native and fractionated RBJ. Fractioned RBJ retained its natural colour, it lacked a specific taste and smell, and the product was sweetish. In an earlier study it was found that fractionated RBJ enhanced iron absorption in intestines, stimulates hematopoiesis, and had pronounced vasodilatating properties (Babarikins et al., 2012). Fractionated RBJ consists of red pigment and complexes of other juice components with molecular weight up to $20000 \mathrm{Da}$. During RBJ fractionation total phenolic compound concentration in the final product practically did not decrease (Table 1).

BM MMCC isolation and identification of the obtained cells. Cultures of rat BM MMSCs that express CD 90 $(95.53 \pm 0.15 \%)$ with lack of expression of CD45 (0.15 \pm $0.01 \%$ ) and potential to differentiate in a mesenchymal cell lineage were isolated.

Impact of RBJ on rat BM MSCs differentiation in vitro. Fractionated RBJ suppressed adipogenic differentiation in both concentrations $(0.1$ and $0.3 \%)$ by $60-71 \%(P<0.05)$, while native RBJ at a lower concentration $(0.1 \%)$ stimulated, but at the highest $(0.3 \%)$ did not suppress adipogenic differentiation significantly (Fig. 1A).

In lower concentration both native and fractionated RBJ did not affect osteogenic differentiation, but at $0.3 \%$ concentration fractionated RBJ in combination with osteogenic me-

Table 1

CHARACTERISTICS OF NATIVE RED BEET JUICE (RBJ) AND FRACTIONATED RBJ

\begin{tabular}{lcc}
\hline \multicolumn{1}{c|}{ Parameter } & Native RBJ & $\begin{array}{c}\text { Fractionated } \\
\text { RBJ }\end{array}$ \\
\hline Density, g/ml & 1.07 & 1.04 \\
Total sugars, g/100 ml & 6.4 & 6.5 \\
Reducing sugars, g/100 ml & 0.34 & 0.37 \\
Pigments - Betalains, mg/100 ml & 103.0 & 92.0 \\
Betacyanins, mg/100 ml & 59.0 & 54.0 \\
Betaxanthins, mg/100 ml & 44.0 & 38.0 \\
Total phenols (as Gallic acid equivalent), & 121.4 & 118.2 \\
mg GAE/ 100 ml & & \\
Iron, mkg/ml & 2.0 & 1.8 \\
Betaine, mg/100 ml & 296 & 245
\end{tabular}


A

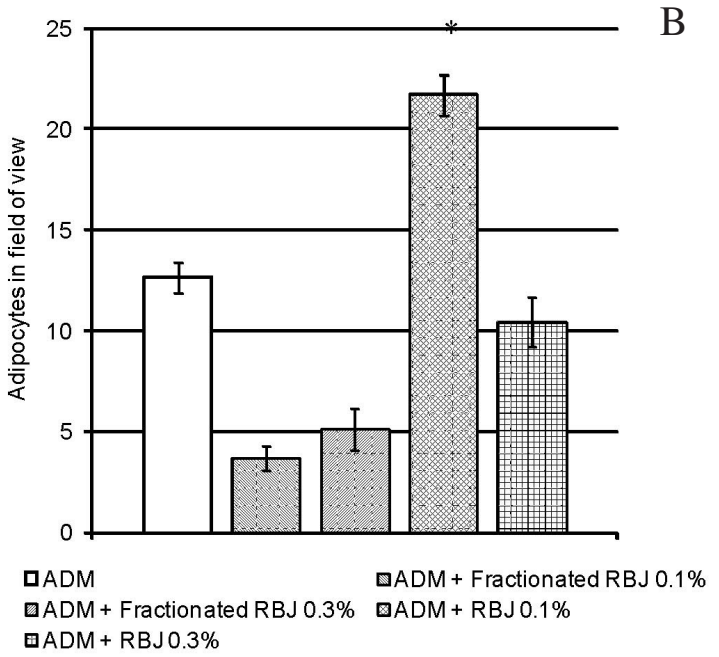

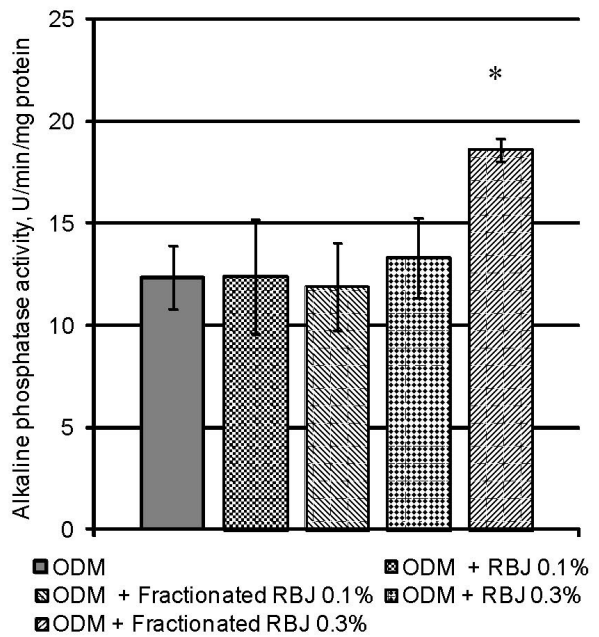

GODM + Fractionated RBJ $0.3 \%$

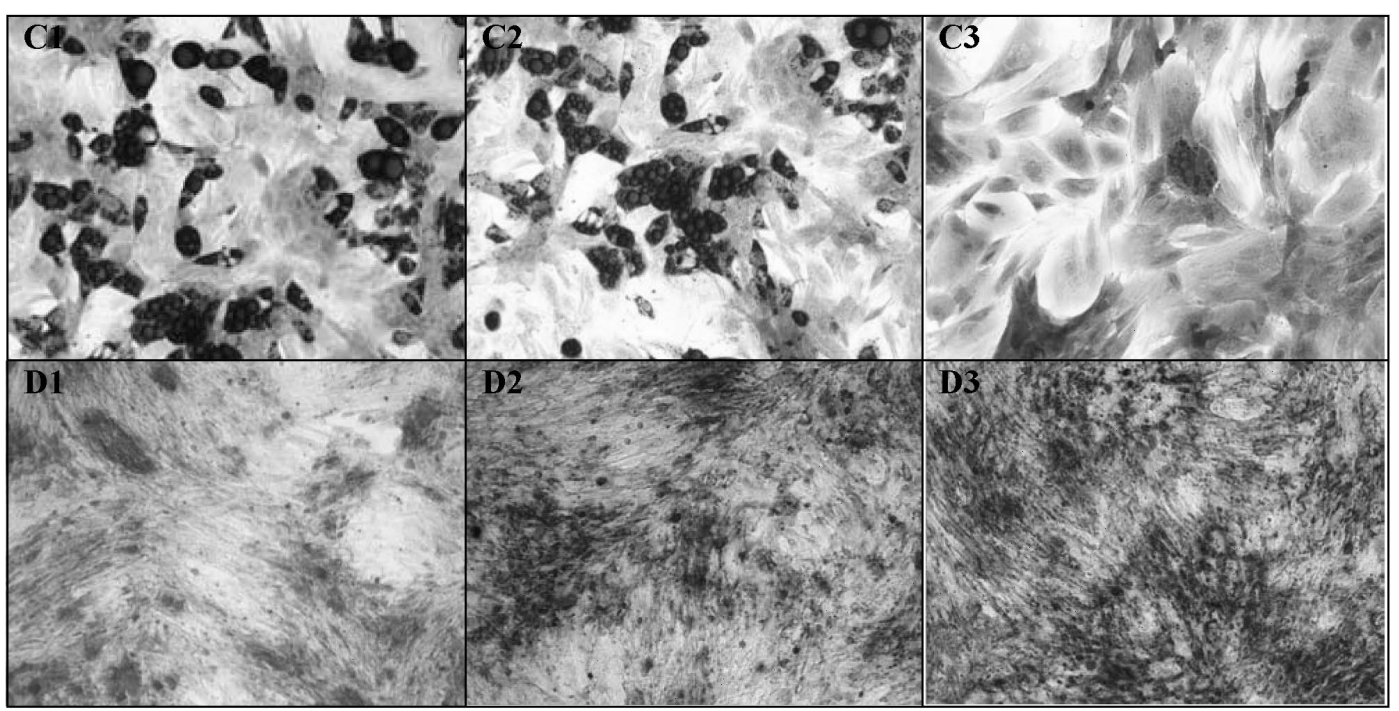

Fig. 1. A, Effect of native and fractionated RBJ on rat BM MMSCs adipogenic differentiation. B, Influence of native and fractionated RBJ on alkaline phosphatase activity in rat BM MMSCs. The error bars represent standard error of the mean $(\mathrm{n}=7)$. ADM, adipogenic differentiation medium; ODM osteogenic differentiation medium; RBJ, red beet juice. ${ }^{*} P<0.05$. C, BM MMSCs at day 21 after beginning of differentiation. Lipid droplet (red) accumulation in cells. Stain - Oil red/Methylen blue. Magnification $\times 200$. C1, Adipogenic differentiation medium; C2, ADM + RBJ 0.3\%; C3, ADM + fractionated RBJ 0.3\%. D, BM MMSCs day 21 after beginning of differentiation. Cell aggregate mineralisation (red). Stain-Alizarin red. Magnification x100. D1, Osteogenic differentiation medium D2, ODM + RBJ 0.3\%. D3, ODM + fractionated RBJ $0.3 \%$.

dium increased activity of alkaline phosphatase by $124 \%$, while native RBJ had no significant effect (Fig. 1B).

Experimental polytrauma in rats. Temperature rise after surgery was observed in all experimental groups (average $\left.+0.3{ }^{\circ} \mathrm{C}\right)$ and occurred approximately four days after surgery (Fig. 2).

Pyrogenic reaction after BM MSC injection was documented in groups 3 and 5 with normalisation at day 10 (Fig. 2). It was supposed that the increase in body temperature in these groups was caused specifically by injection of BM MSCs, as leukocytosis (Fig. 3) was observed in all operated rat groups.

Erythropoiesis (Fig. 4A) in the rat group with untreated polytrauma was slower than in groups that received treatment with BM MMSC transplantation or fractionated RBJ $(P<0.05)$, which is shown also by changes of blood plate- lets count (Fig. 4B). There were no statistical differences between the groups 3,4 and 5, but rats that received BM MMSC transplantation in combination with fractionated RBJ showed a tendency of faster recovery after blood loss (Fig. 4A, 4B).

Polytrauma ( $2^{\text {nd }}$ group) caused a drop of oxygen partial pressure $\left(\mathrm{pO}_{2}\right)$ in blood, which lasted till day 10 (Table 2). Carbon dioxide partial pressure $\left(\mathrm{pCO}_{2}\right)$ in blood also had dropped because of hyperventilation. The $\mathrm{pO}_{2}$ decrease at day 10 for group 5 was the lowest among other polytrauma groups $(P<0.05)$. Acid-base-balance analysis showed that rats with polytrauma developed compensated metabolic and respiratory alkalosis and hyperventilation.

Glucose level in blood increased in the untreated polytrauma group while the lactate level was lower than in other polytrauma groups. In the group 3 glucose level decreased and lactate level increased (Table 2). In group 4 an increase 

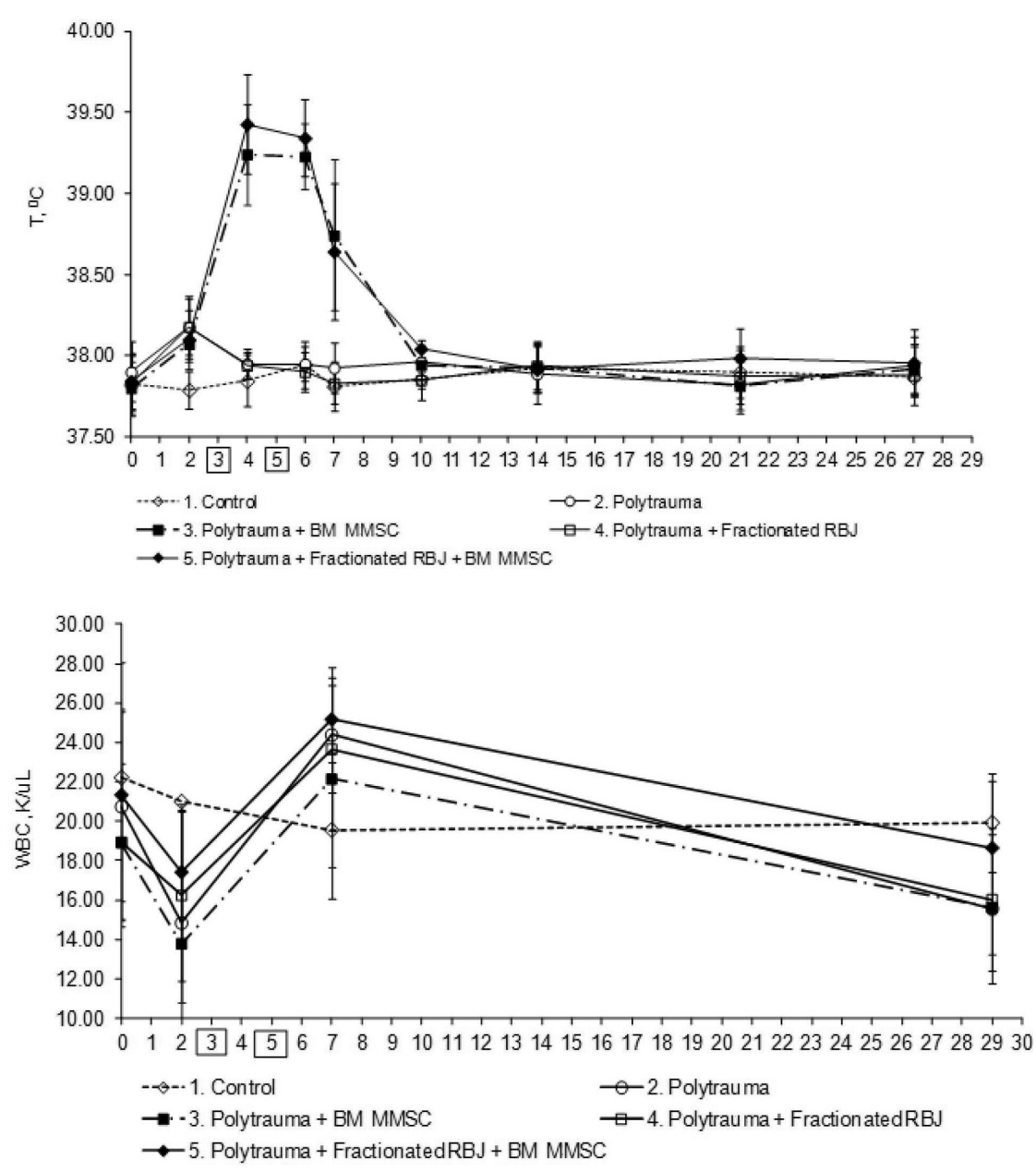

Fig. 2. Temperature dynamics in rats with polytrauma. The error bars represent standard error of the mean $(\mathrm{n}=8)$. $\square$ - Transplantation of BM MMSCs.
Fig. 3. White blood cell (WBC) values in rat groups without and after experimental polytrauma. The error bars represent standard error of the mean $(n=8)$. $\square$ - Transplantation of BM MMSCs. of glucose level was observed while the lactate level decreased. In group 5 glucose level was almost the same as in group 3, but lactate level was highest between all groups (Table 2).

The level of creatinine was lower $(0.054 \pm 0.005 \mathrm{mmol} / \mathrm{l})$ in group 1 compared to $0.061 \pm 0.006 \mathrm{mmol} / 1$ in group $2(P<$ $0.05)$. There were no significant differences between groups with polytrauma (groups 2, 3, 4 and 5)

\section{Morphological changes in lungs and kidneys of rats with} experimental polytrauma. No changes in lungs were observed for the group 1 . In groups 2 and 3 venous plethora and stasis as well as formation of thrombus were observed. In group 3 areas with pneumonial type changes, perhaps with BM MMSC infiltration were seen. In group 4 pulmonary venous plethory was significantly lower than in group 2 , formation of new thrombi was not seen. In group 5 pulmonary distelectasis expanded in comparison, while in group 2 pneumonitis-like changes disappeared.

Animals from the control group (1) had normal kidney structure. In group 2 venous plethora and stasis as well as dystrophy and necrosis of renal epithelium (sights of necrotic nephropathy) was seen. In group 3 venous plethora and formation of thrombus occurred, but dystrophic changes were less than in group 2. In group 4 renal plethora, stasis, and new thrombi occasionally occurred, along with
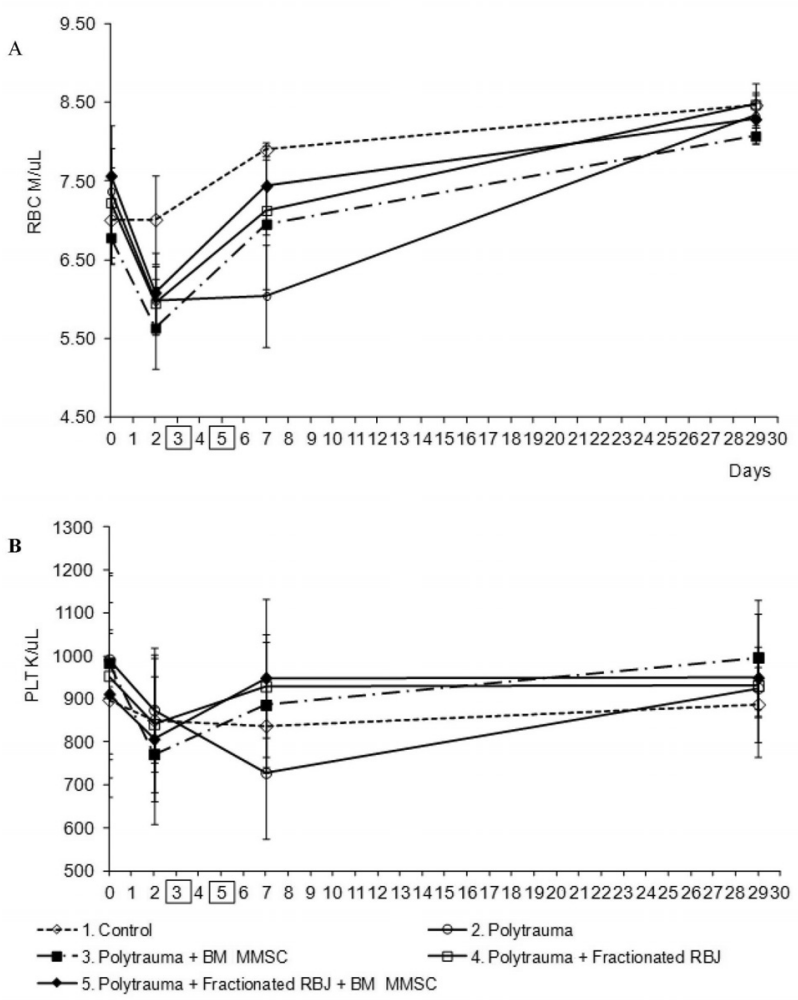

Fig. 4. A, Red blood cell (RBC) values in rat groups without and after experimental polytrauma. The error bars represent standard error of the mean $(n=8)$. B, Platelets (PLT) values in rat groups without and after experimental polytrauma. The error bars represent standard error of the mean $(\mathrm{n}=8)$. $\square$ - Transplantation of BM MMSCs. 
ACID/BASE BALANCE AND GAS PARAMETER DYNAMICS (DAYS 3 AND 10 AFTER SURGERY) IN RATS WITH POLYTRAUMA (mean \pm SD)

\begin{tabular}{|c|c|c|c|c|c|c|}
\hline \multirow[t]{2}{*}{ Group } & \multirow[t]{2}{*}{ Day } & \multicolumn{5}{|c|}{ Parameters } \\
\hline & & $\mathrm{pH}$ & $\mathrm{pCO}_{2}, \mathrm{mmHg}$ & $\mathrm{pO}_{2}, \mathrm{mmHg}$ & Glucose, mmol/l & Lactate, $\mathrm{mmol} / \mathrm{l}$ \\
\hline \multirow[t]{2}{*}{1.} & 3 & $7.30 \pm 0.05$ & $55.87 \pm 10.19$ & $60.86 \pm 10.03$ & $4.40 \pm 0.85$ & $6.25 \pm 0.64$ \\
\hline & 10 & $7.40 \pm 0.07$ & $56.34 \pm 3.19$ & $59.54 \pm 9.38$ & $3.70 \pm 1.63$ & $3.69 \pm 0.57$ \\
\hline \multirow[t]{2}{*}{2.} & 3 & $7.28 \pm 0.03$ & $58.63 \pm 8.34$ & $38.40+4.92$ & $4.78+0.63$ & $6.78 \pm 0.63$ \\
\hline & 10 & $7.35 \pm 0.01$ & $47.70 \pm 3.56$ & $39.45 \pm 2.62$ & $5.6 \pm 0.11$ & $3.83 \pm 0.59$ \\
\hline \multirow[t]{2}{*}{3.} & 3 & $7.31 \pm 0.02$ & $59.98 \pm 7.45$ & $41.33 \pm 3.92$ & $4.20 \pm 0.72$ & $6.88 \pm 0.63$ \\
\hline & 10 & $7.32 \pm 0.05$ & $49.40 \pm 7.68$ & $38.27 \pm 6.96$ & $3.70 \pm 0.83$ & $4.95 \pm 0.86$ \\
\hline \multirow[t]{2}{*}{4.} & 3 & $7.30 \pm 0.04$ & $57.91 \pm 6.12$ & $40.22 \pm 3.18$ & $4.62 \pm 0.50$ & $6.77 \pm 0.52$ \\
\hline & 10 & $7.33 \pm 0.03$ & $46.98 \pm 4.00$ & $37.60 \pm 2.40$ & $5.22 \pm 0.61$ & $3.98 \pm 0.44$ \\
\hline \multirow[t]{2}{*}{5.} & 3 & $7.31 \pm 0.06$ & $58.30 \pm 6.41$ & $42.11 \pm 3.20$ & $4.43 \pm 0.76$ & $6.80 \pm 0.33$ \\
\hline & 10 & $7.40 \pm 0.06$ & $52.40 \pm 3.20$ & $50.07 \pm 4.12$ & $3.85 \pm 0.84$ & $5.88 \pm 0.57 *$ \\
\hline
\end{tabular}

$* P<0.05$ vs groups 4 and 2 .

signs of necrotic nephropathy. In group 5 venous plethory decreased, became inhomogeneous, new thrombi were not identified and distrofic changes disappeared.

Morphological changes in bones. Rats from control group had bone tissue with normal morphologic characteristics.

In the polytrauma group without any treatment active endostal osteoplasy was seen but newly formed bone trabeculae were immature with non-ossificated cartilage incorporation.

In the polytrauma group that received BM MMSC transplantation, consolidation in bone fracture sites was without fibrous cartilage binding. Osteoblast activity remained, but the maturity level of bone trabeculae was higher than in group 2. High haematopoietic activity with blast forms and megakaryocytes was seen as well.

In the polytrauma group that received fractionated RBJ per os, the consolidation level and maturity of trabeculae was the same as in group 3. There was also intensified vascularisation in bone marrow above and under new formation of bone tissue.

In the polytrauma group treated with BM MMSC transplantation and fractionated RBJ, high fracture consolidation and level of trabeculae maturity were observed with prevalence of subperiostal bone tissue reparation. There was intensified vascularisation in bone marrow, high hematopoietic activity with blast forms and megakaryocytes.

\section{DISCUSSION}

Chemical analysis of native and fractionated RBJ showed only slight differences in most of the measured parameters. There were no significant differences in pigment (betacyanin and betaxanthin), total phenol and betaine concentration. This indicated that during fractionation, RBJ retained compounds responsible for the main biological effects of native beetroot juice. At the same time, fractionated RBJ showed new biological properties.

The differences between native and fractionated RBJ effects may be explained by two mechanisms. During the RBJ fractionation some unidentified active compounds were concentrated in the filtrate or during the RBJ fractionation some molecules (with mass more than $20 \mathrm{KDa}$ ) with inhibiting impact on the studied processes had been removed from the RBJ. Both hypotheses are supported by experiments on the antimicrobial activity of fractionated on the basis of molecular mass plant extracts and juices - red chicory, mushroom, raspberry, green and black tea, and cranberry juice, in which low molecular mass fractions were found to be significantly more active than those of high mass (Daglia et al., 2011).

The low molecule fraction of RBJ not only stimulated BM MMSC osteogenic differentiation, but also suppressed adipogenic differentiation in vitro (Fig.1A). These results support those of our study of fractionated RBJ efficacy in obese rats, in which it was observed that it reduced visceral fat mass and improved blood lipid spectra (Babarykin et al., 2011).

In our in vitro studies on BM MMSCs, native and fractionated RBJ did not induce osteogenic differentiation when added to standard cell cultivation medium. In comparison, a phenolic compound called resveratrol isolated from grapes did not affect the first link in beta-catehine dependent Wnt signaling cascade (Zhou et al., 2009). Likewise fractionated RBJ promoted osteogenic differentiation only in combination with the osteogenesis inducing medium that ensured initiation of the process.

Polytrauma is characterised by multiple traumatic injuries and systemic impact: haemorrhagic shock, sepsis, inflammation, and changes in homeostasis. Organism response on polytrauma varies. In our study the main changes influenced by the polytrauma were temperature, blood cell count and creatinine level. 


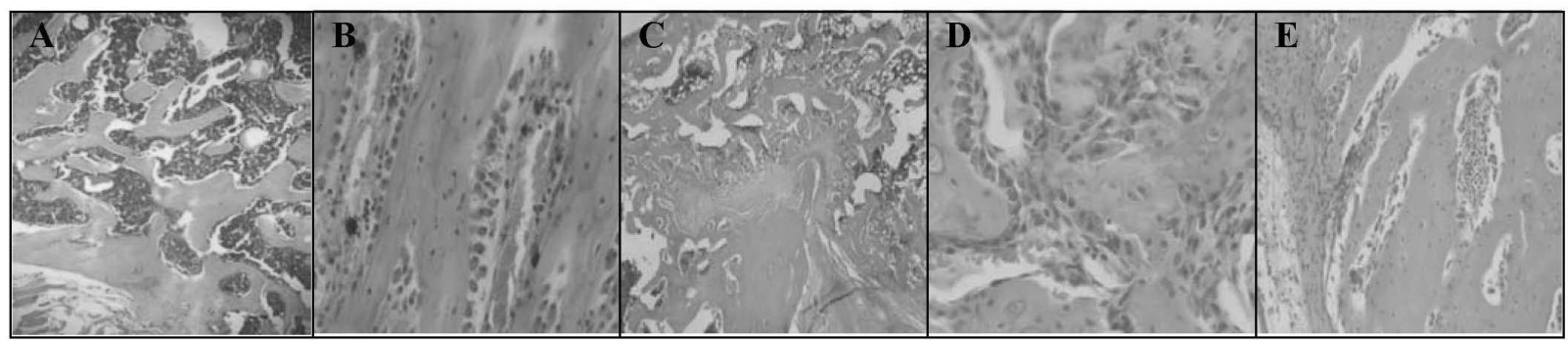

Fig. 5. Morphological changes of bone in rats with polytrauma. Stain - hemotoxylin/eosin. A, Control (1st group). Magnification $\times 100$. Bone tissue with normal morphologic characteristics. B, Polytrauma (2nd group). Magnification $\times 400$. Active endostal osteoplasy. Immature bone trabeculae with non-ossificated cartilage incorporations. C, Polytrauma + BM MMSCs (3rd group) Magnification $\times 100$. Consolidation in bone fracture sites without fibrous cartilage binding. Osteoblast activity remains, but maturity level of bone trabeculae higher than in group 2 . High hematopoietic activity with blast forms and megakaryocytes. D, Polytrauma + fractionated RBJ (4th group). Magnification $\times 400$. Consolidation level and maturity of trabeculae same as in group 3. Intensified vascularisation in bone marrow above and under new formation of bone tissue. E, Polytrauma + BM MMSC + fractionated RBJ (5th group). Magnification $\times 200$. High fracture consolidation and trabeculae maturity level. Prevalence of subperiostal bone tissue reparation. Intensified vascularisation in bone marrow, high hematopoietic activity with blast forms and megakaryocytes.

Pyrogenic reaction after BM MMSCs injection was documented in groups 3 and 5 with normalisation at day 10 (Fig. 2). As leukocytosis (Fig. 3) was observed in all operated rat groups, we consider that this reaction was caused by injection of BM MMSCs. Thermal shock stimulates osteogenesis of BM MMSCs (Nørgaard et al., 2006), and thus arise of temperature could be one of the factors that stimulated bone reparation in these groups.

Blood withdrawal during operation caused anemia (Fig. 4). Treatment with either transplantation of BM MMSC or fractionated RBJ administration per os led to better animal recovery than without treatment, but transplantation of cells together with fractionated RBJ induced the most rapid adaption after haemorrhagic shock.

Polytrauma caused hyperglycemia (group 2, Table 1) and low level of lactate in the blood. The reason for a low lactate may be physical inactivity of the rats. In group 3 with BM MMSCs administration blood glucose concentrations slightly decreased and lactate levels increased, suggesting that the cell injection led to animal physical activity (Table 1). In group 4, there was a rise in blood glucose levels, which could be due to high sugar content of RBJ and also fractionated RBJ as well. Lactate levels, similar to group 2, were low in group 4. In group 5, blood glucose level was similar to group 3, however, the lactate levels increased more than in any other group (Table 1).

Polytrauma in combination with haemorrhagic shock causes apoptosis in liver, lungs and intestine in early stages (Guan et al., 2002). In our study polytrauma induced pulmonary and renal plethory with stasis, and dystrophic changes in the renal epithelium. Morphological changes in kidney corresponded with changes of the creatinine level in blood. Renal insufficiency emerges from polytrauma, and concentration of creatinine was higher $(0.061 \pm 0.006 \mathrm{mmol} / \mathrm{l})$ in group 2 compared to $0.054 \pm 0.005 \mathrm{mmol} / 1$ in group 1 to $(P<0.05)$. There were no significant differences between groups with polytrauma (groups 2, 3, 4 and 5).

BM MMSC injection weakened dystrophic changes in kidneys, but pneumonitis signs in lungs appeared. After frac- tionated RBJ intake thrombi disappeared, except in kidneys. In group 5 animals that received BM MMSCs transplantation and fractionated RBJ, the morphological scene improved in all organs. Lungs are first filter of systemically infused MMSCs. Experiments with mice have shown that injection of allogeneic BM MMSCs causes lung dysfunction and disturbance in blood circulation. Size of MMSCs is bigger than the diameter of lung capillaries. Injection of vasodilatating agent sodium nitroprusside in mice before cell infusion promotes ability of cells to leave lung tissue and decrease symptoms of lung embolism (Schrepfer et al., 2007). Combination of BM MMSCs and fractionated RBJ induces better therapeutic effect on polytrauma healing and reduces side effects of BM MMSCs. It is supposed that fractionated RBJ-induced vasodilatation might enhance the homing effect of BM MMSCs (Gao et al., 2001). The two main compounds of RBJ (phenolic compounds and nitrates) are responsible for vasodilatation.

In bone marrow of rats from groups 3 and 5 high hematopoietic activity was found. This might be explained by transplantation of BM MMSCs: one of their functions in vivo is to support hematopoiesis. Maturity of bone trabeculae in groups 3 and 4 was similar. The conducted in vitro studies indicated that fractionated RBJ has direct impact on BM MMSC activity in animal bone marrow. In group 5, high trabeculae maturity and bone consolidation level as well as elevated hematopoietic activity were observed, showing that fractionated RBJ administration can be used in combination with BM MMSC transplantation in order to improve cell therapy efficacy.

In conclusion, fractionated RBJ in combination with osteogenic medium enhances osteogenesis and when added to adipogenic medium suppresses adipogenic differentiation of rat BM MMSCs in vitro. BM MMSCs and fractionated RBJ show approximately equal efficacy for bone reparation and bone trabeculae maturity level. Transplantation of allogeneic BM MMSCs in rats with experimental polytrauma stimulates bone fracture reparation, but causes plethora in viscera and dystrophic changes in lungs. Combination of 
BM MMSCs and fractionated RBJ resulted in better bone reparation and significant hematopoiesis stimulation.

\section{REFERENCES}

Augello, A., De Bari, C. (2010). The regulation of differentiation in mesenchymal stem cells. Hum. Gene Ther., 21, 1-13.

Babarikins, D., Berzina, N., Aniscenko, A., Krumina, G., Babarikina, A. (2012). Compositions obtainable from bred beetroot juice to promote iron absorption and blood forming. European Pat. EP2420243.

Babarykin, D., Krumina, Z., Krasovska, Z. et al. Kompozīcijas aknu taukainās steatozes novēršanai efektivitātes eksperimentālā izpēte [Experimental investigation of effectiveness of the composition for prevention of fatty liver steatosis]. The 3rd United World Congress of Latvian Scientists and the 4th Letonika (Latvian Studies) Congress, October 24-27, 2011, Rìga, Latvia. Abstracts. Rīga, p. 19 (in Latvian).

Blázovics, A., Sárdi, É., Szentmihályi, K., Váli, L., Takács-Hájos, M., Stefanovits-Bányai, É. (2007). Extreme consumption of Beta vulgaris var. rubra can cause metal ion accumulation in the liver. Acta Biol. Hung., 58 (3), 281-286

Daglia, M., Papetti, A., Mascherpa, D., Grisoli P, Giusto, G., Lingström, P., Pratten, J., Signoretto, C., Spratt, D. A., Wilson, M., Zaura, E., Gazzani, G. (2011). Plant and fungal food components with potential activity on the development of microbial oral diseases. J. Biomed. Biotechnol. doi: $10.1155 / 2011 / 274578$.

Escribano, J., Pedreņo, M.A., Garcķa-Carmona, F., Muņoz, R. (1998). Characterization of the antiradical activity of betalains from Beta vulgaris $\mathrm{L}$. roots. Phytochem. Anal., 9, 124-127.

Freshney, R. I., Stacey, G. N., Auerbach, J. M. (2007). Culture of Human Stem Cells. Wiley. 343 pp.

Gao, J., Dennis, J. E., Muzic, R. F., Lundberg, M., Caplan, A. I. (2001). The dynamic in vivo distribution of bone marrow-derived mesenchymal stem cells after infusion. Cells Tiss. Organs, 169 (1), 12-20.

Georgiev, V. G., Weber, J., Kneschke, E., Denev, P. N., Bley, T., Pavlov, A. I. (2010). Antioxidant activity and phenolic content of betalain extracts from intact plants and hairy root cultures of the beetroot Beta vulgaris cv. Detroit Dark Red. Plant Foods Hum. Nutr., 65 (2), 105-111.

Guan, J., Jin, D. D., Jin, L. J., Lu, Q. (2002). Apoptosis in organs of rats in early stage after polytrauma combined with shock. J. Trauma, 52 (1), 104-111.

Javazon, E. H., Beggs, K. J., Flake, A. W. (2004). Mesenchymal stem cells: Paradoxes of passaging. Exp. Hematol., 32, 414-425.

Jorgensen, C., Djouad, F., Bouffi, C., Mrugala, D., Noèl, D. (2008). Multipotent mesenchymal stromal cells in articular diseases. Best Pract. Res. Clin. Rheumatol., 22 (2), 269-284.

Kapadia, G. J., Azuine, M. A., Sridhar, R., Okuda, Y., Tsuruta, A., Ichiishi, E., Mukainake, T., Takasaki, M., Konoshima, T., Nishino, H., Tokuda, H. (2003). Chemopre-vention of DMBA-induced UV-B promoted, NOR-1-induced TPA promoted skin carcinogenesis, and DENinduced phenobarbital promoted liver tumors in mice by extract of beetroot. Pharmacol. Res., 47, 141-148.

Lian, Q., Zhang, Y., Zhang, J., Zhang, H. K., Wu, X., Zhang, Y., Lam, F. F., Kang, S., Xia, J. C., Lai, W. H., Au, K. W., Chow, Y. Y., Siu, C. W., Lee, C. N., Tse, H. F. (2010). Functional mesenchymal stem cells derived from hu- man induced pluripotent stem cells attenuate limb ischemia in mice. Circulation, 121 (9), 1113-1123.

Murglia, A., Cancedda, R., Quarto, R: (2000). Clonal mesenchymal progenitors from human bone marrow differentiate in vitro according to a hierarchical model. J. Cell Sci., 113, 1161-1166.

Nørgaard, R., Kassem, M., Rattan, S. I. (2006). Heat shock-induced enhancement of osteoblastic differentiation of hTERT-immortalized mesenchymal stem cells. Ann. NY Acad. Sci., 1067, 443-447.

Paderni, S., Terzi, S., Amendola, L. (2009). Major bone defect treatment with an osteoconductive bone substitute. Musculoskelet. Surg., 93, 89-96.

Pape, H. C., Zelle, B., Lohse, R., Stalp, M., Hildebrand, F., Krettek, C., Panzica, M., Duhme, V., Sittaro, N. A. (2006). Evaluation and outcome of patients after polytrauma. Can patients be recruited for long-term follow-up? Injury, 37, 1197-1203.

Schrepfer, S., Deuse, T., Reichenspurner, H., Fischbein, M. P., Robbins, R. C., Pelletier, M. P. (2007). Stem cell transplantation: The lung barrier. Transplant. Proc., 39 (2), 573-576.

Sikand, M., Williams, K., White, C., Morgan, C. G. (2005). The financial cost of treating polytrauma: Implications for tertiary referral centres in the United Kingdom. Injury, 36, 733-737.

Velićanski, A. S., Cvetković, D. D., Markov, S. L., Vulić, J. J., Djilas, S. M. (2011). Antibacterial activity of Beta vulgaris L. pomace extract. APTEFF, 42, 263-269.

Webb, A. J., Patel, N., Loukogeorgakis, S., Okorie, M., Aboud, Z., Misra, S., Rashid, R., Miall, P., Deanfield, J., Benjamin, N., MacAllister, R., Hobbs, A. J., Ahluwalia, A. (2008). Acute blood pressure lowering, vasoprotective, and antiplatelet properties of dietary nitrate via bioconversion to nitrite. Hypertension, 51, 784-790.

Williams, A. R., Hare, J. M. (2011). Mesenchymal stem cells. Biology, pathophysiology, translational findings, and therapeutic implications for cardiac disease. Circ. Res., 109, 923-940.

Winkler, C., Wirleitner, B., Schroecksnadel, K., Schennach, H., Fuchs, D. (2005). In vitro effects of beet root juice on stimulated and unstimulated peripheral blood mono-nuclear cells. Amer. J. Biochem. Biotechnol., 1, 180-185.

Xu, R. X., Chen, J., Cong, X. F., Hu, S., Chen, X. (2008). Lovastatin protects mesenchymal stem cells against hypoxia- and serum deprivation-induced apoptosis by activation of PI3K/Akt and ERK1/2. J. Cell. Biochem., 103 (1), 256-269.

Yang, Y. J., Qian, H. Y., Huang, J., Li, J. J., Gao, R. L., Dou, K. F., Yang, G. S., Willerson, J. T., Geng, Y. J. (2009). Combined therapy with simvastatin and bone marrow-derived mesenchymal stem cells increases benefits in infarcted swine hearts. Arterioscler. Thromb. Vasc. Biol., 29 (12), 2076-2082.

Zhou H., Shang L., Li X., Zhang X., Gao G., Guo C., Chen B., Liu Q., Gong Y., Shao C. (2009). Resveratrol augments the canonical Wnt signaling pathway in promoting osteoblastic differentiation of multipotent mesenchymal cells. Exp. Cell Res., 315 (17), 2953-2962.

Мальгинов Н. Н., Григорьян А. С., Фролова Е. Н., Лебеденко И. Ю., Матвеева В. Н., Воложин А. И. (2009). Структурная организация костного регенерата в экспериментально воспроизведенных дефектах ветви нижней челюсти под влиянием ксеногенных стромальных клеток [Bone regenerate structural organization in experimentally reproduced defects of mandible branches under xenogenic stromal cells influеnсе]. Стоматология (Москва), 88 (4), 34-38.

Received 11 December 2012 
ALOGĒNO KAULU SMADZEN̦U MULTIPOTENTO MEZENHIMĀLO STROMĀLO ŠŪNU IZMANTOŠANA POLITRAUMAS TERAPIJĀ: PĒC MOLEKULMASAS FRAKCIONĒTA SARKANO BIEŠU SULA MAZINA TRANSPLANTĒTO ŠŪNU IZRAISĪTĀS BLAKUSPARĀDĪBAS

Diagnoze politrauma ietver ne tikai mehāniskas iedarbības uz k̦ermeṇa dạ̄ām, bet arī ar nopietnas sistēmiskas izmaiṇas, ieskaitot išēmiju, hipoksiju, infekciju. Tādēḷ ārstēšanai jābūt kompleksai. Šūnu terapija spētu ne tikai veicināt bojāto audu reǵenerāciju, bet arī modulēt sistēmiskās izmaiṇas organismā. Pieredze rāda, ka šūnu tehnolog̣iju efektivitāte pieaug, ja tiek izmantoti farmakoloğiski līdzekḷi transplantēto šūnu funkciju regulācijai in vivo. Tie ne tikai palīdz novērst transplantēto šūnu izraisītās blaknes, bet arī uzlabo terapijas efektivitāti. Pētījuma mērķis bija novērtēt kaulu smadzeņu multipotento mezenhimālo stromālo šūnu (KS MMSŠ) i/v transplantācijas un ar ultrafiltrāciju no sarkano biešu (Beta vulgaris) sulas (SBS) izdalīta produkta perorālas ievadīšanas vai abu kombinētas terapijas efektivitāti politraumas ārstē̌šanā. Wistar-Kyoto līnijas žurku tēviṇi $(\mathrm{n}=35)$ tika randomizēti sadalīti piecās grupās: 1) kontrole (veseli); 2) politrauma; 3) politrauma + KS MMSŠ transplantācija; 4) politrauma + frakcionēta sarkano biešu sula; 5. politrauma + KS MMSŠ + frakcionēta SBS. Tika izmantots eksperimentāls politraumas modelis ar trīs kaulu lūzumiem kombinācijā ar hemorāǵisko šoku. Trīsdesmit dienu laikā alogēno KS MMSŠ transplantācija žurkām ar eksperimentālo politraumu veicināja ātrāku fiziskās aktivitātes atgūšanu, kā arī kaulu lūzumu reparāciju. Tajā pašā laikā šūnu pārstādīšana izraisīja iekšējo orgānu pilnasinību un veicināja distrofiskas izmaiņas plaušās. Kombinējot šūnu i/v infūziju ar frakcionētas SBS perorālu ievadīšanu $(1 \mathrm{ml} /$ dienā), tika nodrošināts labākais dzīvnieku rehabilitācijas efekts ar minimālām blaknēm. 